\title{
Nový pohled na genezi ordovické oolitické rudy z ložiska Skalka u Mníšku pod Brdy (pražská pánev, Barrandien)
}

\author{
New insight into the origin of Ordovician oolitic iron ores from Skalka Deposit near \\ Mníšek pod Brdy (Prague Basin, Barrandian)
}

David Buriánek $\stackrel{1}{\hookrightarrow}$, Miroslav Bubík' ${ }^{1}$ Dalibor Všianský ${ }^{2}$

'Česká geologická služba, Leitnerova 22, 60200 Brno

2 Ústav geologických věd PřF MU, Kotlářská 2, 61137 Brno

Key words:

Barrandian, Ordovician, oolitic iron ores, mineral composition, diagenesis, depositional environment, Czech Republic

$\square$ david.burianek@geology.cz

Editor:

Marek Slobodník

\begin{abstract}
The Skalka Deposit near Mníšek pod Brdy currently represents one of the best exposed localities of Ordovician oolitic iron ores in the Barrandian. The studied oolitic iron ores consist mainly of siderite ( $\mathrm{Fe}=1.47-1.86 \mathrm{apfu})$ and kaolinite ( $\mathrm{Si}=7.99-8.06 \mathrm{apfu} ;{ }^{\mathrm{VI}} \mathrm{Al}=$ 7.62-7.67 apfu). This mineral association has been formed as a result of the process of diagenesis and has resulted from the decomposition of chlorite and $\mathrm{Fe}$-(oxo-)hydroxides. Presence of colofane indicates rather low temperatures for this transformation. Paleontological record makes the previous hypothesis, that the iron ore deposit was formed in an isolated depression separated from the Prague Basin by a flat elevation, questionable. The presence of abundant graptolites and agglutinated foraminifers in the shales of the Šárka Formation indicates rather deep-water open-marine conditions. Ferruginous ooids are typically formed on shoals affected by wave action. The presence of these ooids in deep-water shale and existence of oolitic iron ore deposit accompanied by this shale does not need to be explained by sudden shallowing, but more likely by reworking of ooids in gravity flows to sublittoral or bathyal depths. Original position of shoal was most likely situated towards NNW where ore deposit and finally the complete Šárka Formation disappear. The fossil record indicates open-marine realm southeast of the Skalka area.
\end{abstract}

\section{Úvod}

Ordovický sedimentační cyklus pražské pánve je poměrně bohatý na ložiska železných rud. Bylo definováno 17 rudních obzorů (Petránek 1965). Zrudnění zde tvoří především oolitické sideritové a hematitové rudy (Petránek 1975). Jejich výskyt je typický především pro příbřežní oblasti pražské pánve. V šáreckém souvrství se zrudnění vyskytuje jako různě mocné čočky.

Ložisko Skalka vzniklo v ordoviku na z. okraji Gondwany a leželo poblíž vulkanických ostrovních oblouků (Linnemann et al. 2004). Na přelomu kambria a ordoviku začal rozpad Gondwany a docházelo k postupnému otvírání Rheického oceánu (např. von Raumer, Stampfli 2008). Během tohoto rozpadu kulminovala vulkanická aktivita svázaná s riftingem (Drost et al. 2011). Právě s tímto vulkanizmem je časově a někdy také prostorově svázán rozvoj sedimentace železných rud. Ložisko Skalka u Mníšku pod Brdy je jednou z typických lokalit oolitických rud v Barrandienu a její studium může přispět k pochopení toho, proč právě během staršího paleozoika kulminuje výskyt tohoto typu mineralizace v sedimentárním záznamu. Tato studie mapuje procesy vzniku zdejších oolitických rud a změny, které způsobila diageneze. 


\section{Geologická pozice}

Ložisko Skalka u Mníšku pod Brdy je situováno při okraji jv. kř́ídla pražské pánve Barrandienu (obr. 1). Podloží ordovických sedimentů tvoří spodnokambrické sedimenty zastoupené hlavně hořickými pískovci (Petránek 1975). Na bázi ordoviku popisují Svoboda a Prantl (1946) lokálně vyvinuté zelenošedé slepencovité tufitické pískovce řazené ke „komárovským vrstvám“ (klabavské souvrství). Zároveň autoři připouštějí, že bazální poloha mocná jen 1-2 m může patřit již k šáreckému souvrství. Výše následují břidlice šáreckého souvrství mocné okolo $10 \mathrm{~m}$. Zrudnění se nachází v šáreckém souvrství a v menší míre v nadložních břidlicích o mocnosti okolo $20 \mathrm{~m}$. Tyto břidlice patří již k dobrotivskému souvrství (Chlupáč et al. 2002). Výše se nacházejí skalecké křemence dobrotivského souvrství značné mocnosti (obr. 1). Vrcholovou



Obr. 1: A - Geologická situace ložiska Skalka v centrální části tepelsko-barrandienské oblasti (upraveno podle Chlupáče et al. 2002) 1 - silur a devon; 2 - ordovik; 3 - kambrium; 4 - proterozoikum; B - zjednodušená geologická mapa studované oblasti (upraveno podle Maška 1999 a Havlíčka 1986) 5 - kvartérní sedimenty; 6 až 9 ordovik (6 - pískovce až křemence; 7 - břidlice; 8 - železné rudy a břidlice; 9 - vulkanity), 10-11 kambrium (10 - slepence; 11 - droby až pískovce); 12 - proterozoikum (prachovce, droby); 13 - ústí štoly Skalka; C - linie geologického řezu ložiskem Skalka (upraveno podle Svobody a Prantla 1946) 14 - střední kambrium; 15-16 - šárecké souvrství (15 - břidlice; 16 - železné rudy), 17 a 18 - dobrotivské souvrství (17 - břidlice; 18 - skalecké křemence); 19 - libeňské souvrství (řevnické křemence).

Fig. 1: A - Geological position of the Skalka Deposit in central part of Teplá-Barrandian Unit (after Chlupáč et al. 2002, modified) 1 - Silurian and Devonian; 2 - Ordovician; 3 - Cambrian; 4 - Proterozoic; B - simplified geological map of the study area (after Mašek 1999 and Havlíček 1986, modified) 5 - Quaternary sediments; 6 to 9 Ordovician (6 - sandstones to quartzites; 7 - shales; 8 - iron ore and shales; 9 - volcanites), 10 and 11 Cambrian (10 - conglomerates; 11 - greywacke to sandstones); 12 - proterozoic (greywackes, sandstones); 13 - entrance of the Skalka gallery; C - line of geological section of the Skalka Deposit (after Svoboda and Prantl 1946, modified) 14 - Middle Cambrian; 15 and 16 - Šárka Formation (15 - shales; 16 - iron ore); 17 and 18 - Dobrotivá Formation (17 - shales; 18 - Skalka quartzites); 19 - Libeň Formation (̌̌evnice Quartzites). 
část masivu Skalky tvoří řevnické křemence libeňského souvrství.

V šáreckém souvrství se oolitické železné rudy zastupují s černými jílovitými břidlicemi. Jde o jemnozrnné břidlice s dominancí illitu a šupinkami muskovitu na foliačních plochách. Běžné jsou laminy hrubšího siltu (Kukal 1963). Břidlice místy přecházejí do prachovců a písčitých břidlic s polohami pískovců.

Ložisko železných rud vzniklo během středního ordoviku (darriwil) po velkém hiátu, který lokálně zabírá interval vyšší spodní kambrium až spodní ordovik. V období ordoviku se popisovaná lokalita nacházela na okraji Gondwany a byla situována na j. polokouli v oblasti kolem 50 rovnoběžky. Klima bylo poměrně chladné, na což ukazují výskyty chladnovodní fauny i převaha klastických sedimentů (Chlupáč 1992).

Ve studované oblasti rudy nasedají přímo na sedimenty středního kambria, což bývá vysvětlováno morfologií terénu před začátkem sedimentace železných rud. Předpokládalo se, že oolitické rudy vznikly v příbřežních lagunách a hlavním zdrojem železa byly vulkanity křivoklátského pásma (Bouček 1947; Chlupáč et al. 2002; Havlíček 1981).

\section{Historie ložiska}

Železné rudy na ložisku Skalka u Mníšku pod Brdy těžili na povrchových výchozech patrně již Keltové. Hlubinná těžba se datuje od 18. století. $Z$ této doby existuje i důlní mapa, na které je zachycena jáma sv. Antonína Paduánského s poměrně vysokým stupněm rozfárání ložiska. V roce 1852 těžba zanikla (Zelenka, Živor 2019). K novým pokusům o otevření ložiska došlo až na začátku 20. století a těžba s přestávkami probíhala až do 60 . let 20. století, kdy bylo ložisko vytěženo (Petránek 1975; Zelenka, Živor 2019). Dnes je část dolu zpřístupněna pro geoturistiku (Hošek 2017).
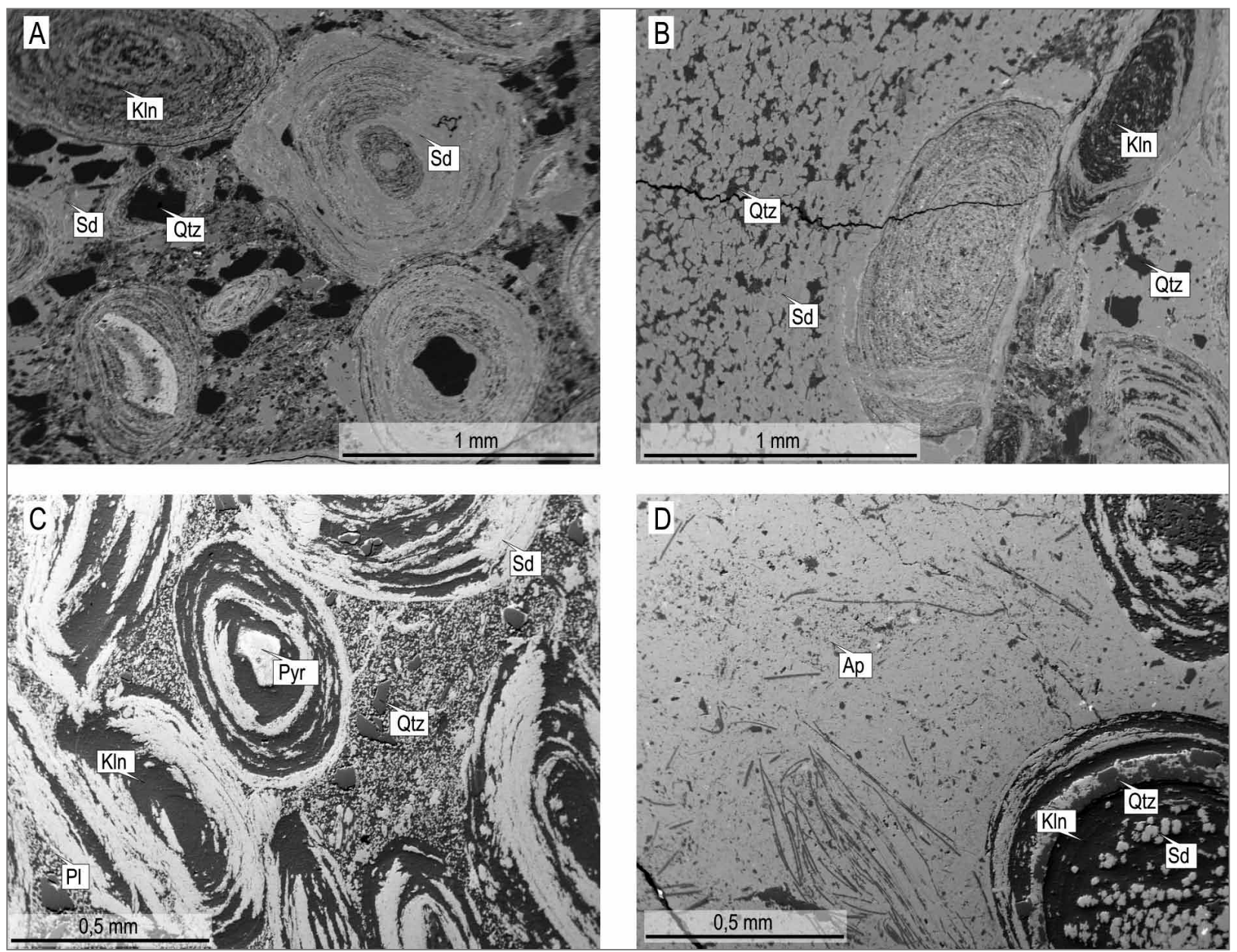

Obr. 2: Petrografie oolitických Fe rud, BSE snímky: A - deformované ooidy, v centrální části ooidů jsou klasty křemene nebo bioklasty; B - kontakt mezi masivní sideritovou rudou ( $\mathrm{Sd}$ - siderit, světlá fáze, Qtz - křemen, tmavá fáze) a oolitickou rudou; C - deformované ooidy složené z kaolinitu (Kln), sideritu a pyritu (Pyr); D - intraklast kolofánu (Ap) uzavírající drt' kutikul fylokaridů (dole uprostřed).

Fig. 2: Petrography of the oolitic Fe ore, back-scattered electron (BSE) images: A - Deformed ooids, quartz grain or bioclasts form core of ooids; B - Contact between massive siderite (Sd - siderite, light phase, Qtz - quartz, dark phase) and oolites ore; C - Deformed ooids composed of kaolinite (Kln), siderite and pyrite (Pyr); D - colophane (Ap) intraclast enclosing phyllocarid cuticle fragments. 
Tab. 1: Analýzy karbonátů (hm. \%) a empirické vzorce přepočtené na základ 6 kyslíků ve vzorcové jednotce.

Tab. 1: Carbonate analyses (wt.\%) and empirical formulas recalculated on the basis of 6 oxygens per formula unit.

\begin{tabular}{|l|c|c|c|c|}
\hline Vzorek & $\mathbf{7 0 6 / N}$ & $\mathbf{7 0 6 / N}$ & $\mathbf{S 1 2 0 1 5}$ & $\mathbf{S 1 2 0 1 5}$ \\
\hline ćíslo & $\mathbf{3 2}$ & $\mathbf{3 3}$ & $\mathbf{4}$ & $\mathbf{5}$ \\
\hline $\mathrm{CaO}$ & 0,98 & 0,53 & 1,01 & 0,86 \\
\hline $\mathrm{MgO}$ & 1,43 & 4,23 & 3,22 & 3,65 \\
\hline $\mathrm{MnO}$ & 0,47 & 0,26 & 0,04 & 0,00 \\
\hline $\mathrm{FeO}$ & 58,55 & 55,96 & 54,17 & 52,01 \\
\hline $\mathrm{SrO}$ & 0,00 & 0,04 & 0,04 & 0,00 \\
\hline $\mathrm{CO}_{2}$ & 38,49 & 39,49 & 37,52 & 36,53 \\
\hline celkem & 99,92 & 100,51 & 95,99 & 93,07 \\
\hline $\mathrm{Ca}$ & 0,040 & 0,021 & 0,042 & 0,037 \\
\hline $\mathrm{Mg}$ & 0,081 & 0,234 & 0,187 & 0,218 \\
\hline $\mathrm{Mn}$ & 0,015 & 0,008 & 0,001 & 0,000 \\
\hline $\mathrm{Fe}$ & 1,864 & 1,736 & 1,769 & 1,745 \\
\hline $\mathrm{Sr}$ & 0,000 & 0,001 & 0,001 & 0,000 \\
\hline $\mathrm{C}$ & 2,000 & 2,000 & 2,000 & 2,000 \\
\hline $\mathrm{O}^{\mid}$ & 6,000 & 6,000 & 6,000 & 6,000 \\
\hline komponenta (mol. \%) & 2 & 1 & 2 & 2 \\
\hline $\mathrm{CaCO}_{3}$ & 4 & 12 & 9 & 11 \\
\hline $\mathrm{MgCO}_{3}$ & 4 & 0 & 0 & 0 \\
\hline $\mathrm{MnCO}_{3}$ & 1 & 87 & 88 & 87 \\
\hline $\mathrm{FeCO}_{3}$ & 93 &
\end{tabular}

\section{Metodika}

Studované vzorky (6 vzorků železné rudy a 2 vzorky břidlic) z důlního díla Skalka odebrali D. Buriánek a J. Hošek. Část výsledků získaných studiem těchto vzorků byla využita při přípravě bakalářské práce (Hošek 2017). Zmíněné výsledky jsou však v rámci tohoto článku reinterpretovány. Analýzy minerálů byly provedeny na elektronové mikrosondě Cameca SX-100 (Laboratoř elektronové mikroskopie a mikroanalýzy, Ústav geologických věd PřF MU a Česká geologická služba). Měření probíhalo ve vlnově disperzním módu za následujících analytických podmínek: urychlovací napětí $15 \mathrm{kV}$; průměr elektronového svazku $5 \mu \mathrm{m}$, proud svazku $10 \mathrm{nA}$, načítací čas 10-20 s pro hlavní prvky, 20-60 s pro stopové prvky; operátor P. Gadas. Byly použity tyto standardy: Si, K, $\mathrm{Al}$ - sanidin, $\mathrm{Mg}$ - $\mathrm{MgO}, \mathrm{Fe}$ - almandin, $\mathrm{Ca}$ - grosulár, $\mathrm{Mn}$ - spesartin, Ti - titanit, $\mathrm{Cr}$ - chromit, $\mathrm{Na}$ - albit, $\mathrm{Sr}$ $\mathrm{SrSO}_{4}, \mathrm{P}$ - fluorapatit, $\mathrm{F}$ - topaz, $\mathrm{Cl}-\mathrm{NaCl}, \mathrm{Zn}$ - gahnit, $\mathrm{V}$ - vanadinit, $\mathrm{Cu}-\mathrm{Cu}, \mathrm{Y}-\mathrm{YAG}$. Obsahy prvků byly přepočteny PAP korekcí (Pouchou, Pichoir 1985).

Pro rentgenovou práškovou difrakční (RTG) analýzu byl vybrán jeden vzorek oolitické železné rudy a jeden vzorek břidlice šáreckého souvrství. Oba vzorky byly před analýzou rozdrceny pomocí kovového vibračního mlýna a naneseny v tenké vrstvě na folii.

Práškové rtg-difrakční (PXRD) analýzy byly provedeny na aparatuře Rigaku Smartlab s Cu-anodou $(\lambda \mathrm{Ka}=$ $0,15418 \mathrm{~nm}$ ) a $1-\mathrm{D}$ pozičně citlivým detektorem při konvenční Bragg-Brentano parafokusační $\Theta-\Theta$ reflexní geometrii. Úhlová oblast $4-80^{\circ} 2 \Theta$, krok $-0,02^{\circ} 2 \Theta$, čas na krok - $1 \mathrm{~s}$. Získaná data byla zpracována pomocí software Panalytical High Score 4.5 plus a Bruker AXS EVA 2. Orientační kvantitativní fázová analýza byla provedena Rietveldovou metodou pomocí strukturních
Tab. 2: Analýzy kaolinitu (hm. \%) a empirické vzorce přepočtené na základ 36 aniontů ve vzorcové jednotce. Obsahy Fe jsou pod detekčním limitem.

Tab. 2: Kaolinite analyses (wt.\%) and empirical formulas recalculated on the basis of 36 anions per formula unit.

\begin{tabular}{|c|c|c|c|}
\hline Vzorek & S12015 & S12015 & S12015 \\
\hline číslo & 1 & 2 & 3 \\
\hline $\mathrm{SiO}_{2}$ & 48,13 & 48,94 & 48,53 \\
\hline $\mathrm{TiO}_{2}$ & 0,14 & 0,21 & 0,39 \\
\hline $\mathrm{Al}_{2} \mathrm{O}_{3}$ & 39,03 & 39,04 & 38,86 \\
\hline $\mathrm{Cr}_{2} \mathrm{O}_{3}$ & 0,05 & 0,07 & 0,04 \\
\hline $\mathrm{Fe}_{2} \mathrm{O}_{3}$ & 1,22 & 1,17 & 1,06 \\
\hline $\mathrm{MnO}$ & 0,00 & 0,01 & 0,02 \\
\hline $\mathrm{MgO}$ & 0,16 & 0,12 & 0,10 \\
\hline $\mathrm{CaO}$ & 0,43 & 0,19 & 0,15 \\
\hline $\mathrm{Na}_{2} \mathrm{O}$ & 0,04 & 0,04 & 0,03 \\
\hline $\mathrm{K}_{2} \mathrm{O}$ & 0,59 & 0,60 & 0,47 \\
\hline $\mathrm{F}$ & 0,06 & 0,03 & 0,07 \\
\hline $\mathrm{Cl}$ & 0,01 & 0,01 & 0,01 \\
\hline $\mathrm{H}_{2} \mathrm{O}^{*}$ & 14,29 & 14,44 & 14,31 \\
\hline $\mathrm{O}=\mathrm{F}, \mathrm{Cl}$ & 0,03 & 0,02 & 0,03 \\
\hline TOTAL & 104,11 & 104,85 & 104,00 \\
\hline $\mathrm{Si}$ & 7,992 & 8,063 & 8,049 \\
\hline${ }^{\mathrm{IV}} \mathrm{Al}$ & 0,008 & 0,000 & 0,000 \\
\hline pozice $\mathrm{T}$ & 8,000 & 8,063 & 8,049 \\
\hline${ }^{\mathrm{VI}} \mathrm{Al}$ & 7,674 & 7,622 & 7,636 \\
\hline $\mathrm{Ti}$ & 0,017 & 0,025 & 0,049 \\
\hline $\mathrm{Cr}$ & 0,006 & 0,009 & 0,006 \\
\hline $\mathrm{Fe}^{3+}$ & 0,152 & 0,145 & 0,132 \\
\hline vakance & 3,760 & 3,857 & 3,904 \\
\hline pozice $\mathrm{R}^{3+}$ & 11,609 & 11,659 & 11,725 \\
\hline $\mathrm{Mn}$ & 0,000 & 0,001 & 0,003 \\
\hline $\mathrm{Mg}$ & 0,039 & 0,028 & 0,024 \\
\hline $\mathrm{Ni}$ & 0,000 & 0,000 & 0,000 \\
\hline $\mathrm{Zn}$ & 0,000 & 0,000 & 0,000 \\
\hline $\mathrm{Ca}$ & 0,077 & 0,033 & 0,026 \\
\hline $\mathrm{Na}$ & 0,025 & 0,027 & 0,021 \\
\hline $\mathrm{K}$ & 0,249 & 0,252 & 0,201 \\
\hline $\mathrm{Ba}$ & 0,000 & 0,000 & 0,000 \\
\hline $\mathrm{Rb}$ & 0,000 & 0,000 & 0,000 \\
\hline pozice $\mathrm{R}^{2+}$ & 0,391 & 0,341 & 0,275 \\
\hline $\mathrm{F}$ & 0,062 & 0,031 & 0,071 \\
\hline $\mathrm{Cl}$ & 0,005 & 0,007 & 0,004 \\
\hline $\mathrm{OH}^{*}$ & 15,933 & 15,962 & 15,924 \\
\hline
\end{tabular}

dat z databáze ICSD 2012. Obsah rentgenoamorfní fáze nebyl stanovován.

Studium výbrusů bylo provedeno na mikroskopu Nikon Eclipse ME600 mikrofotografie pořízeny kamerou Nikon DS-U3. Mikropaleontologický vzorek břidlice byl připraven drcením na hydraulickém lisu, desintegrován mechanicky s použitím gumové zátky a plaven na sítu $0,063 \mathrm{~mm}$ v laboratoři ČGS. Fotodokumentace foraminifer byla pořízena na mikroskopu Nikon SMZ1500 vybaveném kamerou ProgResCT3 a upravena pomocí software NIS-Elements. Dokladový fosilní a výbrusový materiál je součástí hmotné dokumentace ČGS v Brně.

\section{Mineralogie a petrografie oolitické rudy}

Podrobně byly v optickém mikroskopu a elektronovou mikrosondou studovány dva vzorky oolitických 

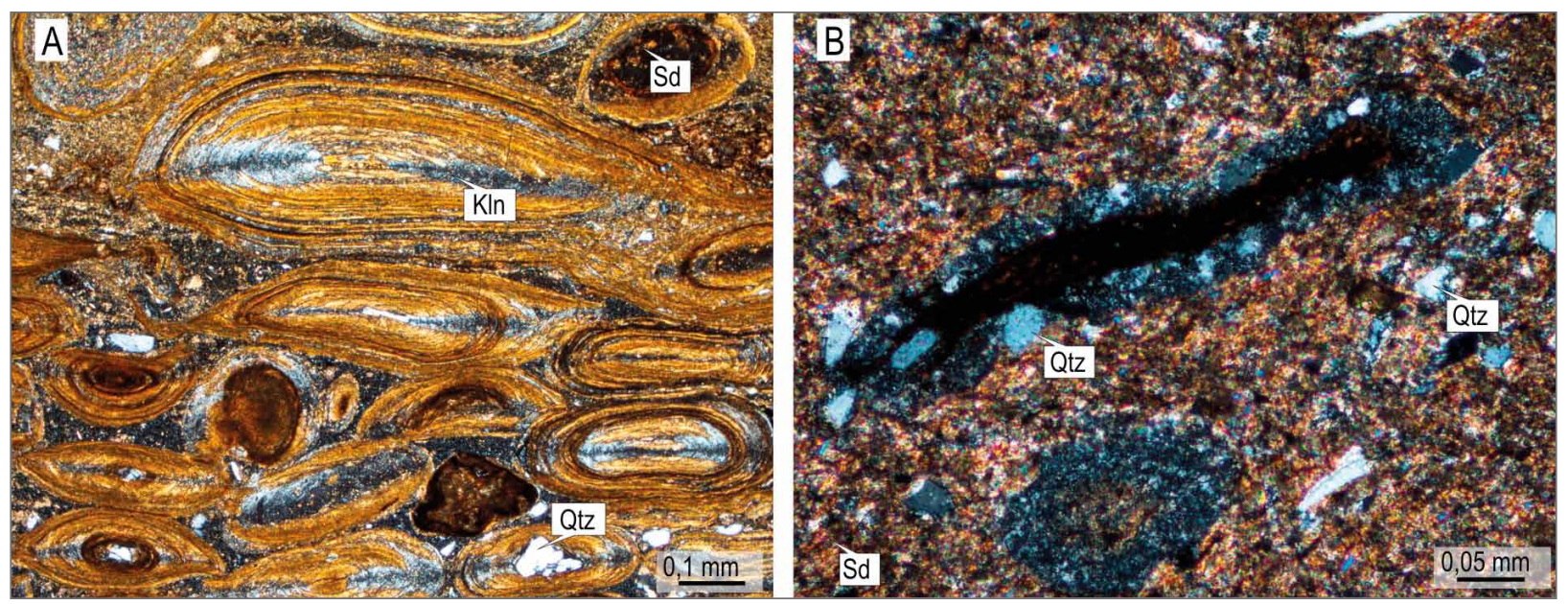

Obr. 3: Petrografie oolitických Fe rud, optické (XPL) snímky: A - deformované ooidy obsahují segmenty bohaté kaolinitem; B - schránka aglutinované foraminifery Thuramminoides sp. v písčité břidlici mezi vrstvami oolitické železné rudy. Zkratky minerálů stejné jako na obrázku 2.

Fig. 3: Petrography of the oolitic Fe ore, optical (XPL): A - deformed ooids contain kaolinite-rich sectors; B - agglutinated foraminifer test Thuramminoides sp. in sandy shale interbedded with the oolitic iron ore. Mineral abbreviations same as in Figure 2.

rud odebrané z 16 patra dolu. Jedná se o tmavě červené drobnozrnné horniny s variabilním zastoupením ooidů o velikosti kolem $1 \mathrm{~mm}$ (obr. 2A). Mezi vrstvami oolitických rud o mocnosti až několik cm se vyskytují drobné laminy a vrstvy tvořené jemnozrnnou hematitovou až sideritovou rudou (obr. 2B), pelity nebo prachovci.

Siderit $(\mathrm{Fe}=1,74-1,86$ apfu, tab. 1) je dominantním rudním minerálem. Vyskytuje se v podobě drobných zrn (kolem 0,03-0,1 mm) přímo v ooidech nebo v základní hmotě, která je obklopuje. Jednotlivá zrna v základní hmotě mají často oscilační zonálnost, přičemž vedle Fe kolísá hlavně zastoupení $\mathrm{Mg}(0,08-0,23 \mathrm{apfu})$. Centrální část ooidu je tvořena často drobnými paprsčitými agregáty sideritu nebo je jemně zrnitý siderit součástí jednotlivých vrstev ooidů, někdy společně s hematitem. Některé větší krystaly prorůstají vrstevnaté struktury v ooidech. Chemické složení sideritu v ooidech je charakterizováno nižší variabilitou zastoupení dolomitové komponenty $(\mathrm{Mg}=$ 0,19-0,22 apfu).

Hematit je poměrně běžnou součástí ooidů a tvoří základní hmotu zdejších železných rud (Petránek 1975). Ve studovaných vzorcích však byl většinou přítomen jako jemně rozptýlený pigment $\mathrm{v}$ některých ooidech a v základní hmotě, který byl dobře patrný v optickém mikroskopu.
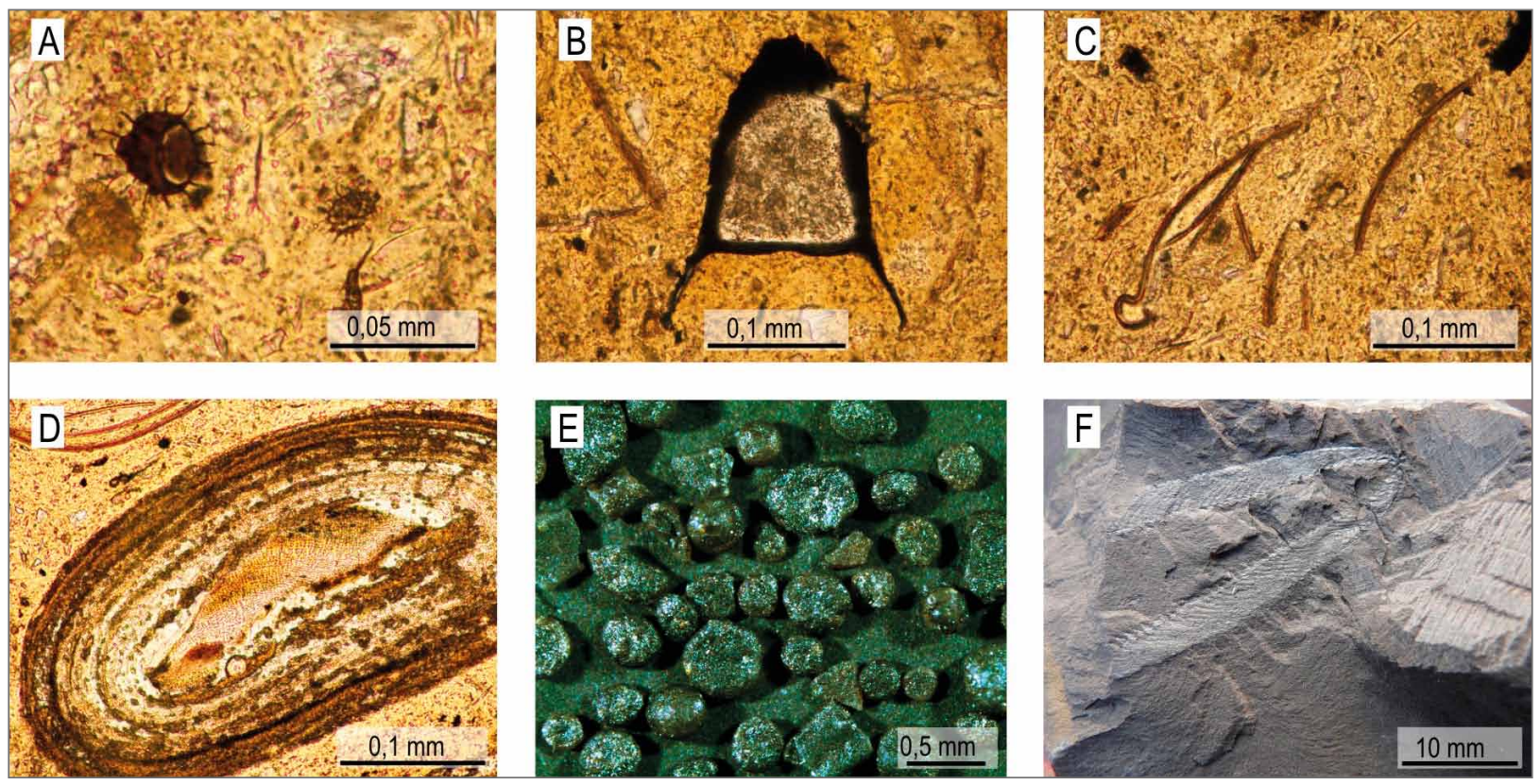

Obr. 4: Charakteristické fosílie šáreckého souvrství z ložiska Skalka: A - akritarcha; B - chitinozoa; C - kutikuly fylokaridů Caryocaris sp.; D - destička ostnokožce v jádru Fe-ooidu; E - foraminifery Thuramminoides sp.; F - graptolit Didymograptus clavulus; A-D: oolitická ruda, výbrus, NL; E, F - břidlice.

Obr. 4: Characteristic fossils of the Šárka Fm. from Skalka Ore Deposit: A - Acritarcha; B - Chitinozoa; C - cuticle fragments of Caryocaris sp.; D - echinoderm plate as a core of Fe ooide; E - foraminifers Thuramminoides sp.; F - graptolite Didymograptus clavulus; A-D: oolitic iron ore, thin section, NL; E, F - shale. 
Tab. 3: Analýzy apatitu (hm. \%) a empirické vzorce přepočtené na základ 13 aniontů ve vzorcové jednotce. Obsahy $\mathrm{Cl}$ jsou pod detekčním limitem.

Tab. 3: Apatite analyses (wt.\%) and empirical formulas recalculated on the basis of 13 anions per formula unit.

\begin{tabular}{|l|c|c|}
\hline Vzorek & $\mathbf{S 1 2 0 1 5}$ & $\mathbf{S 1 2 0 1 5}$ \\
\hline ćíslo & $\mathbf{6}$ & $\mathbf{7}$ \\
\hline $\mathrm{P}_{2} \mathrm{O}_{5}$ & 40,40 & 40,86 \\
\hline $\mathrm{SiO}_{2}$ & 1,46 & 1,74 \\
\hline $\mathrm{CaO}$ & 52,75 & 53,73 \\
\hline $\mathrm{SrO}$ & 0,12 & 0,16 \\
\hline $\mathrm{La}_{2} \mathrm{O}_{3}$ & 0,03 & 0,04 \\
\hline $\mathrm{Ce}_{2} \mathrm{O}_{3}$ & 0,15 & 0,01 \\
\hline $\mathrm{Nd}_{2} \mathrm{O}_{3}$ & 0,00 & 0,13 \\
\hline $\mathrm{Y}_{2} \mathrm{O}_{3}$ & 0,03 & 0,02 \\
\hline $\mathrm{Al}_{2} \mathrm{O}_{3}$ & 0,41 & 0,83 \\
\hline $\mathrm{FeO}$ & 1,08 & 0,58 \\
\hline $\mathrm{MgO}$ & 0,06 & 0,05 \\
\hline $\mathrm{F}$ & 3,45 & 3,45 \\
\hline $\mathrm{OH}$ & 0,11 & 0,14 \\
\hline total & 100,04 & 101,74 \\
\hline $\mathrm{O}=\mathrm{F}$ & 1,45 & 1,46 \\
\hline $\mathrm{TOTAL}$ & 98,59 & 100,29 \\
\hline $\mathrm{P}$ & 2,918 & 2,892 \\
\hline $\mathrm{Si}$ & 0,124 & 0,145 \\
\hline $\mathrm{Ca}$ & 4,821 & 4,813 \\
\hline $\mathrm{Sr}$ & 0,006 & 0,008 \\
\hline $\mathrm{La}$ & 0,001 & 0,001 \\
\hline $\mathrm{Ce}$ & 0,005 & 0,000 \\
\hline $\mathrm{Nd}$ & 0,000 & 0,004 \\
\hline $\mathrm{Y}$ & 0,001 & 0,001 \\
\hline $\mathrm{Al}$ & 0,041 & 0,081 \\
\hline $\mathrm{Fe}$ & 0,077 & 0,041 \\
\hline $\mathrm{Mg}$ & 0,007 & 0,006 \\
\hline $\mathrm{XFAp}$ & 0,93 & 0,91 \\
\hline $\mathrm{XHAp}$ & 0,07 & 0,09 \\
\hline & & \\
\hline & & \\
\hline
\end{tabular}

Chlority a jílové minerály jsou poměrně běžnou součástí ooidů, přičemž Petránek (1975) uvádí především illit a chamozit. Chamozit se však ve studovaných vzorcích nepodařilo zjistit a zastoupení illitu je proměnlivé (podle pozorovánív elektronovém mikroskopu se pohybuje jeho obsah od 0,5 do několika desítek hmot. \%).

$\mathrm{V}$ ooidech je běžně obsažen kaolinit $(\mathrm{Si}=7,99-8,06$ apfu; ${ }^{\mathrm{VI}} \mathrm{Al}=7,62-7,67 \mathrm{apfu}$; tab. 2). Kaolinit se většinou vyskytuje $\mathrm{v}$ ooidech v podobě tenkých vrstev, které se stř́idají s vrstvami sideritu (obr. 2B). V některých ooidech se však koncentruje do sektorů, které jsou protažené souhlasně s protažením deformovaných ooidů (obr. 3A)

Pyrit (případně také markazit) je ve vzorcích poměrně vzácný a byl zjištěn ve formě drobných zrnek v základní hmotě. Rovněž byl pozorován hematitizovaný kubický krystal tvořící krystalizační jádro jednoho z ooidů (obr. $2 \mathrm{C}$ ). Jádra některých ooidů tvoří ojediněle bioklasty, jako např. destička ostnokožce (obr. 4D).

Fosfority tvoří základní hmotu mezi některými ooidy a vzácně také vystupují jako až $4 \mathrm{~mm}$ velké intraklasty. Podle optických vlastností a RTG analýzy se jedná se o kolofán (obr. 2D), což je amorfní až kryptokrystalická odrůda apatitu (fluorapatitová komponenta
Tab. 4: Výsledky kvantitativní fázové analýzy krystalického podílu vzorků ( $\mathrm{hm} . \%)$, zaokrouhleno na jedno desetinné místo (sk-b-215 = břidlice, sk-fe-215 = železná ruda).

Tab. 4: The results of the quantitative phase analysis of the crystalline fraction in the samples (wt.\%), rounded to one decimal place (sk-b-215 $=$ shale, sk-fe-215 $=$ iron ore) .

\begin{tabular}{|l|c|c|}
\hline Vzorek/fáze & sk-b-215 & sk-fe-215 \\
\hline Křemen & 25,5 & 4,4 \\
\hline Siderit & 11,3 & 30,0 \\
\hline Kaolinit & 2,2 & 45,7 \\
\hline Illit & 60,7 & 18,9 \\
\hline Anatas & 0,3 & 0,0 \\
\hline Markazit? & 0,0 & 1,0 \\
\hline
\end{tabular}

tvoří 91-93 mol. \%, zbytek je amorfní hydroxyapatit, tab. 3). Uvnitř inktraklastu je patrná koncentrická stavba s ostrohrannými klastickými zrny křemene. Itraklast je lemován ooidy. V centrální ćásti intraklastu jsou agregáty framboidálního pyritu. Fosforitová základní hmota obsahuje poměrně hojné téměř nedeformované palynomorfy: Acritarcha a Chitinozoa (obr. 4A, B). Na okrajích intraklastu se vyskytuje drt' kutikul fylokaridů (obr. 2D, 4C).

Křemen a další klastická příměs jsou běžnou součástí obou vzorků studovaných elektronovou mikrosondou. Křemen je přítomen jako polozaoblené až ostrohranné klasty o velikost od $0,1-0,3$ mm (obr. 2C, 3B). Křemen však také vystupuje i jako součást tmelu mezi ooidy (jemně zrnité agregáty). Vzácně se objevují lupínky muskovitu.

$\mathrm{V}$ břidlicích se místy vyskytují schránky aglutinovaných foraminifer (obr. 3B, 4E).

\section{Rentgenová prášková difrakce (RTG)}

Výsledky RTG poměrně dobře doplnily mineralogii sedimentů. Pro studium byl použit vzorek typické břidlice (sk-b-215) a oolitické železné rudy (sk-fe-215). Výsledky orientační kvantitativní fázové analýzy krystalického podílu vzorků jsou uvedeny v tabulce 4 , difraktogramy na obrázcích 5 a 6 . $Z$ důvodu přehlednosti jsou $\mathrm{v}$ obrázcích uvedeny pouze úhlové oblasti $4-40^{\circ} 2 \Theta$. Nelze vyloučit, že kromě illitu se v obou vzorcích vyskytují i jiné minerály ze skupiny slíd, které mohou být vlivem koincidence difrakčních linií v polyfázových vzorcích navzájem obtížně odlišitelné.

Vzorek břidlice šáreckého souvrství můžeme charakterizovat jako tmavě šedou až černou břidlici s proplástky prachovců. Na vrstevních plochách jsou patrné lupínky světlé slídy. Pro RTG analýzu byla zvolena jemnozrnná poměrně tmavá část vzorku bez pyritových krystalů. Břidlice obsahuje kolem $61 \%$ ilitu a $26 \%$ křemene; kolem $11 \%$ horniny tvoří siderit a $2 \%$ kaolinit. Ve stopovém množství je prítomen anatas (0,3\%). Difuzní pozadí difraktogramu vzorku sk-b-215 s maximem cca 3,3 Å indikuje relativně vysoký obsah rentgenoamorfní fáze. Amorfní fáze je patrně zastoupena oxo-hydroxidy Fe a organickou hmotou (zjištěno na základě studia výbrusů).

V oolitické rudě mezi krystalickými fázemi dominuje kaolinit (46\%), siderit (30\%) a výrazně je zastoupen také illit. Křemen je př́tomen pouze v obsahu kolem $4 \%$. Difuzní pozadí vzorku sk-fe-215 s maximem kolem 6,6 A souvisí s přítomností rentgenoamorfní fáze a jedná se 


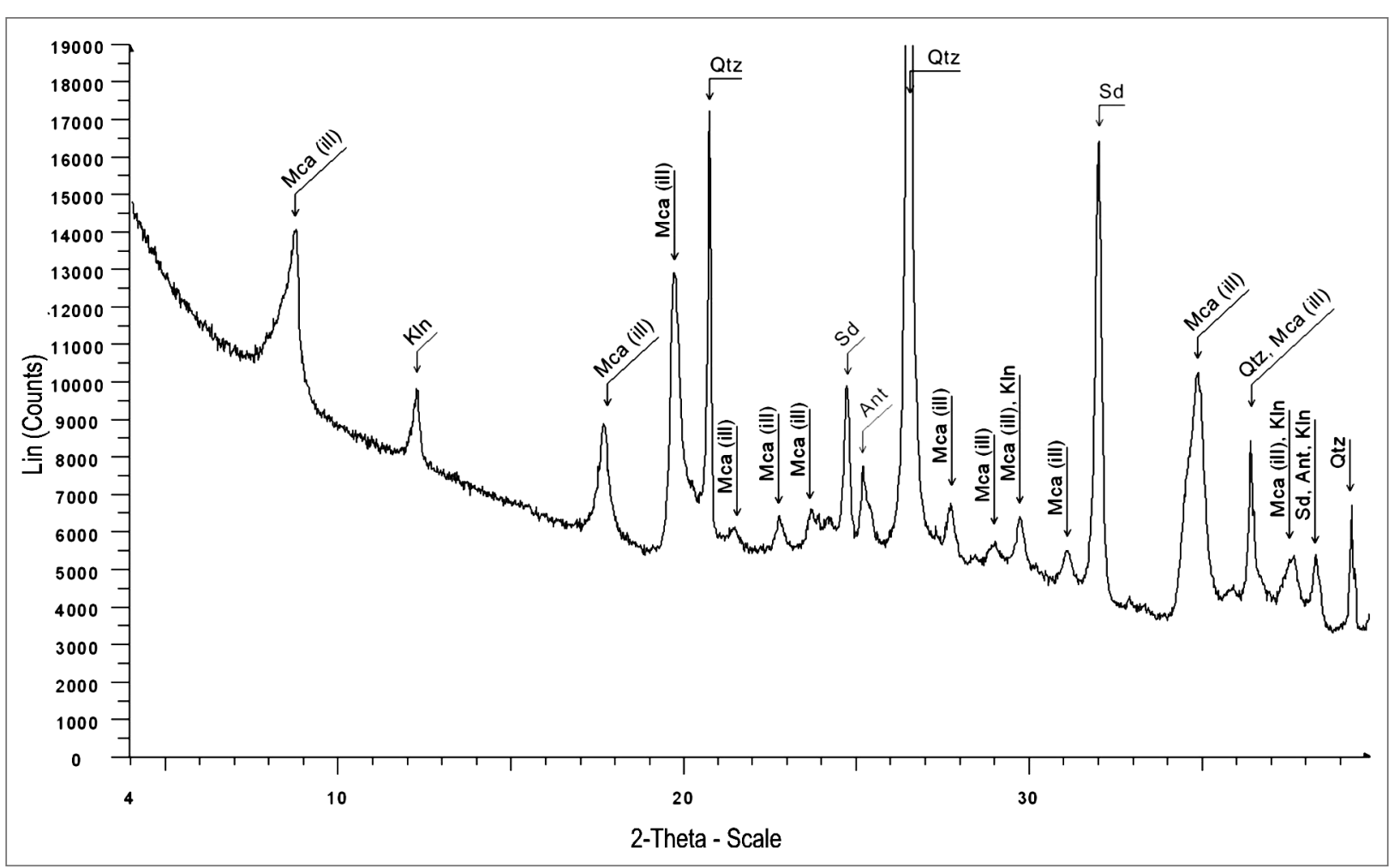

Obr. 5: Difraktogram vzorku břidlice (sk-b-215) s výrazným difuzním pozadím; úhlová oblast 4-40² $\Theta$. (zkratky: https://www. bgs.ac.uk/downloads/start.cfm?id=3197).

Fig. 5: Shale specimen diffractogram (sk-b-215) with a distinct diffusion background; angular area $4-40^{\circ} 2 \Theta$ (abbreviations: https://www.bgs.ac.uk/downloads/start.cfm?id=3197).

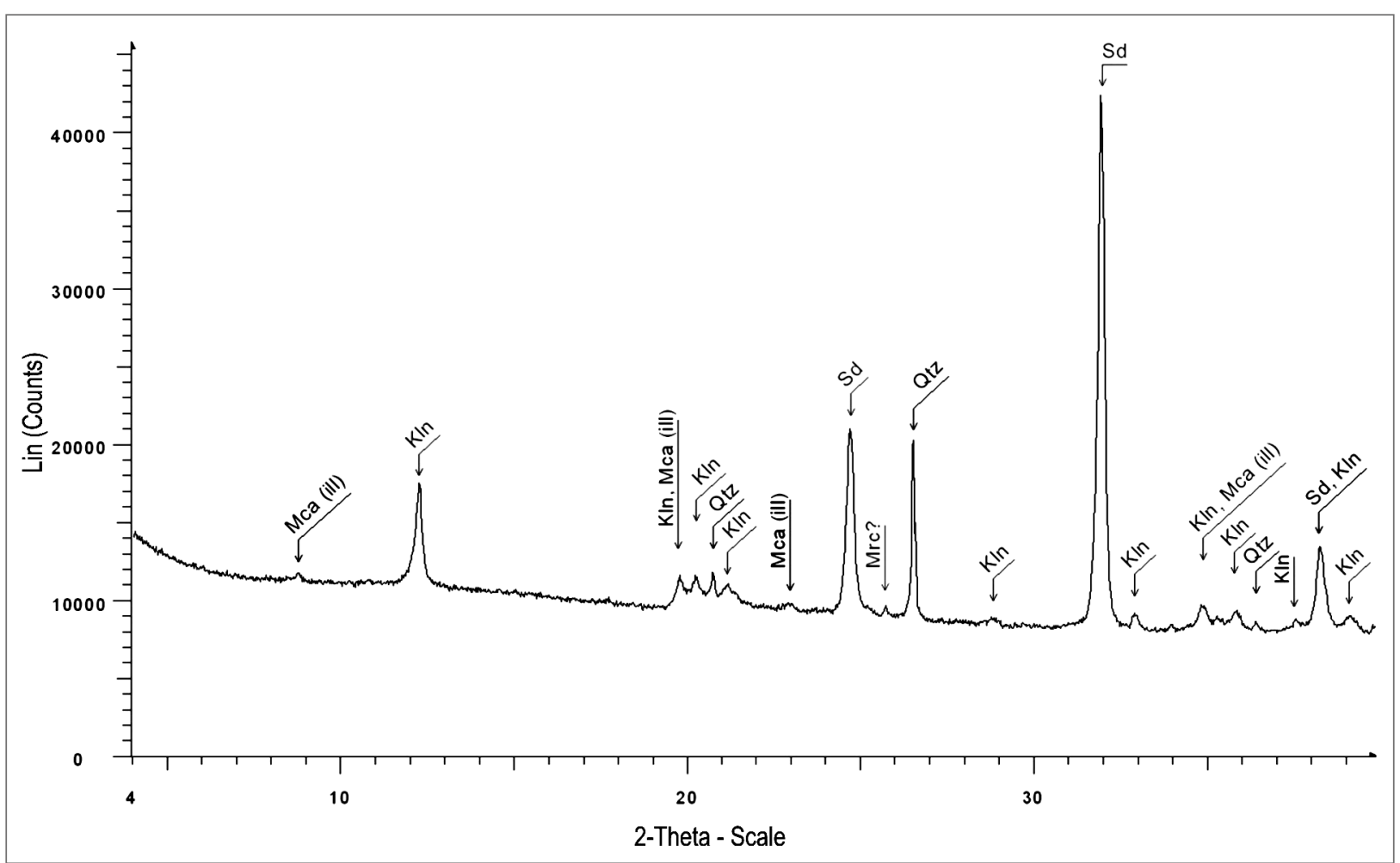

Obr. 6: Difraktogram vzorku železné rudy (sk-fe-215) s výrazným difuzním pozadím; úhlová oblast 4-40² $2 \Theta$ (zkratky https:// www.bgs.ac.uk/downloads/start.cfm?id=3197).

Fig. 6: Iron ore specimen diffractogram (sk-fe-215) with a distinct diffusion background; angular area $4-40^{\circ} 2 \Theta$ (abbreviations: https://www.bgs.ac.uk/downloads/start.cfm?id=3197). 
pravděpodobně o směs fosfátů (kolofán) a oxo-hydroxidů Fe. Př́itomnost markazitu ve vzorku sk-fe-215 nelze vzhledem $\mathrm{k}$ jeho nízkému obsahu jednoznačně potvrdit.

\section{Diskuze \\ Podmínky a prostředí vzniku rud na lokalitě Skalka u Mnišku}

Železem bohaté ooidy byly popsány v recentních sedimentech v okolí vulkanického oblouku v Indonésii (Sturesson et al. 2000). Zde vznikají ooidy precipitací železa v bezprostřední blízkosti horkých pramenů (Heikoop et al. 1996). Na základě prrítomnosti úlomků vulkanických hornin a podle obsahu stopových prvků však někteří autoři (např. Sturesson 1995, 2003) interpretují většinu oolitických rud jako produkt sedimentace železa, které se uvolnilo $\mathrm{v}$ důsledku rozpadu vulkanického popela (zejména vulkanického skla) během zvětrávání.

V Barrandienu je sepětí mezi ordovickými železnými rudami a vulkanizmem dobře patrné na řadě lokalit, avšak ne vždy je vztah mezi vulkanizmem a sedimentací železných rud jednoznačně prokázán (Petránek 1975; Skoček 1963). Podle Petránka (1975) je nutné v př́padě mníšeckého ložiska hledat zdroj železa na přilehlé pevnině. Většinou se předpokládá, že bylo uvolněno v důsledku zvětrávání (např. Havlíček 1981). Při našem studiu se ve zkoumaném rudním obzoru nepodařilo nalézt úlomky vulkanických hornin. Polozaoblená klastická zrna křemene naznačují, že zdrojové horniny (patrně hlavně vulkanického původu) prošly intenzivním zvětráváním a díky tomu se uvolnilo železo, které pak bylo transportováno vodními toky do príbřežních (subtidálních) oblastí pražské pánve.

Minerální složení ooidů je výrazně závislé na jejich vývoji během sedimentace a diageneze. $\mathrm{V}$ oxidačním prostředí vznikají ooidy s převahou limonitu a $\mathrm{v}$ anoxickém prostřední dominují chloritové ooidy (Sturesson et al. 2000). Vznik ooidů může také souviset s vývojem mikrobiálních povlaků (Dahanayke, Krumbein 1985). Na lokalitě Skalka u Mníšku byly nalezeny oolitické železné rudy obsahující oxidy a karbonáty Fe. Původně však byla větší část ooidů tvořena chloritem (viz níže). Ooidy obsahují četné bioklasty a křemenná zrna. To je v těchto rudách poměrně běžný jev a souvisí se vznikem ooidů v příbřežních (subtidálních) oblastech (Einsele 1992). Vliv mikrobiálních povlaků na tvorbu ooidů naznačuje přítomnost fosforitových intraklastů (Hiatt et al. 2015).

Podle Kukala (1962) byl sedimentační prostor rudního ložiska Skalka u Mníšku uzavřenou zátokou, která byla od otevřeného moře (dále na SZ) částečně izolována hřbetem budovaným kambrickými horninami. Existenci ploché elevace předpokládá rovněž Chlupáč et al. (1992). Vtělenský (1959) soudil, že mníšecké ložisko není vysloveně mělčinným ložiskem, nicméně také předpokládal sedimentaci v zálivu. Železem bohaté usazeniny zde byly při ústupu moře dočasně obnaženy nebo se alespoň částečně dostaly do oxidačních podmínek př́břežní zóny a přitom byly druhotně oxidovány. Podle Vtělenského (1959) hojná písčitá př́iměs a vložky pískovců v šáreckých břidlicích indikují mělkovodní sedimentační podmínky v nevelké vzdálenosti od pobřeží.

Jestliže vyjdeme $\mathrm{z}$ geologického řezu sestaveného Svobodou a Prantlem (1946), můžeme vysledovat pozici elevace oddělující hypotetický záliv od centrální části pražské pánve (obr. 1b). Na jihojihovýchodním okraji synklinální struktury hřbetu Skalky začíná ordovický vrstevní sled tenkou polohou řazenou některými autory ke komárovskému komplexu, resp. klabavskému souvrství. Výše leží šárecké břidlice s Didymograptus clavulus Perner a na nich hlavní ložisková poloha oolitických rud, nad kterou následuje již dobrotivské souvrství (břidlice, skalecké křemence).

Směrem k SSZ na vzdálenosti pouhých 200 m vyklíní tenká poloha klabavského souvrství a poté i břidlice šáreckého souvrství, takže oolitické rudy nasedají přímo na kambrický podklad a tvoří celou mocnost šáreckého souvrství. Podle řezu Litochleba (2012) rudní poloha a potažmo šárecké souvrství zcela vykliňují dále $\mathrm{k}$ SSZ.

Tato situace nabízí představu, že elevace se nacházela v místě dnešní synklinální struktury Skalky a mělčina na jejím vrcholu produkovala železité ooidy. Pokračování ložiskové polohy k JJV mohlo být vytvořeno redepozicí ooidů vlivem vlnění a gravitačních proudů.

Mezi Mníškem pod Brdy a Řevnicemi, přes $2 \mathrm{~km}$ ssz. od dolu Skalka, byly ve vrtech zastiženy břidlice šáreckého souvrství s makrofaunou (D. clavulus, trilobiti, fylokaridi, brachiopodi) a oolitickými smouhami, které jsou pravděpodobně laterálním ekvivalentem ložiskové polohy na Skalce (Svoboda, Prantl 1946). Tato facie dokládá redepozici ooidů z elevace směrem do centra pražské pánve.

V tmavošedé břidlici v podloží ložiskové rudní polohy na 16. patře dolu Skalka byl nově ověřen četný výskyt graptolitů Didymograptus clavulus (obr. 4F). Makrobentos (trilobiti, brachiopodi, měkkýši) nebyl zjištěn vủbec. Ukazuje to na příznivé životní podmínky v eufotické zóně a dobrou komunikaci s otevřeným mořem a zároveň hypoxii ve vodách u dna.

Břidlice šáreckého souvrství jsou díky své tmavé barvě považovány za produkt sedimentace v nedostatečně prokysličeném až anoxickém prostředí (Kukal 1963). $\mathrm{Na}$ druhé straně byly $\mathrm{z}$ břidlic získány poměrně četné aglutinované foraminifery, které lze předběžně řadit $\mathrm{k}$ rodu Thuramminoides. Tato fauna je $\mathrm{v}$ tmavých břidlicích šáreckého souvrství mezi Prahou a Plzní běžná (např. Holcová 1999; Bubík 2001). Početné populace eukaryot (foraminifer) za absence makrofauny ukazují, že na povrchu dna panovala spíše dysoxie než anoxie. Anoxie se však mohla nacházet bezprostředně pod rozhraním voda/ sediment. Procesy kompakce a rané diageneze už tudíž mohly probíhat v plně anoxických podmínkách. Výskyt destičky ostnokožce tvořící jádro Fe-ooidu (viz obr. 4D) naopak indikuje oxické prostředí vzniku ooidů, byt’ jen lokálně nebo epizodicky.

Paleobatymetrické úvahy se mohou opírat především o zbytky autochtonního bentosu, což jsou v př́ípadě lokality Skalka aglutinované foraminifery. V ordoviku Barrandienu jsou foraminifery rozšířeny spíše 
v hlubokovodních pelitických faciích a chybí v okrajových (mělčích) a vulkanosedimentárních faciích. Například v podložním klabavském souvrství se foraminifery vyskytují v zelenavých eulomových břidlicích, ale chybí v okrajové facii červených olešenských břidlic a ve faciích s vložkami tufitů. Rovněž hojný výskyt planktonických graptolitů ukazuje na otevřené moře. Okrajové facie jsou charakteristické výskytem dendroidů na úkor planktonických graptolitů. Ačkoli prostor sedimentace šáreckého souvrství v oblasti Mníšku pod Brdy byl oddělen od pražské pánve plochou elevací, fosilní záznam ukazuje spíše na další oblast otevřeného moře na JJV než na izolovaný záliv nebo lagunu.

Odhadnout hloubku prostředí ordovického moře $\mathrm{v}$ metrech je nesnadný úkol a aktualistický přístup není použitelný. $\mathrm{V}$ př́padě břidlic $\mathrm{v}$ těsném podloží oolitických rud lze hypoteticky uvažovat o hloubkách hlubšího sublitorálu až bathyálu (zhruba mezi 100 až $1000 \mathrm{~m}$ ).

Na kontaktu mezi oolitickými rudami a břidlicemi šáreckého souvrství pozorujeme bezprostřední zastupování mezi oxidovanými železnými rudami a tmavými anoxickými břidlicemi. Tento typ sedimentu vznikl $\mathrm{v}$ důsledku podmořských skluzů. Fosfátový intraklast $\mathrm{v}$ železných rudách vznikal patrně také $\mathrm{v}$ redukčních podmínkách, jak o tom svědčí nálezy po zbytcích pyritových framboidů (Hiatt et al. 2015). V intraklastu byly ve výbrusu pozorovány hojné akantomorfní typy akritarch, chitinozoa a drt’ kutikul fylokaridů, což jsou charakteristické skupiny mořského planktonu a nektonu v ordoviku.

\section{Diagenetické pochody}

Ve většině studovaných vzorků dominují zploštělé ooidy, což však také může souviset s jejich vznikem. Ooidy v okolí horkých pramenu totiž získávají eliptický tvar již při precipitaci $z$ mořské vody (Sturesson et al. 2000). Naše pozorování však potvrdila, že tvar ooidů je ovlivněn hlavně působením směrného tlaku během diageneze. Do ooidů jsou často $\mathrm{z}$ vnějšku vtlačena klastická zrna a jednotlivé ooidy se vzájemně deformují. Podle Skočka (1963) jsou ooidy uložené v jílovitých sedimentech postižené deformacemi mnohem více než ostatní.

V oolitických železných rudách patř́i siderit k nejmladším minerálům. Skoček (1963) předpokládá, že siderit nebyl primární součástí ooidů, protože sideritové krystaly nerespektují jejich koncentrickou nebo radiálně paprsčitou strukturu. Podle Vtělenského (1959) je krystalizace sideritu druhotným procesem, při němž dochází $\mathrm{k}$ růstu větších krystalů, které porušují hladké vrstvy ooidů a některé ooidy až téměř zanikají. Tento jev indikuje velký vliv $\mathrm{CO}_{2}$ na diagenetické procesy v oolitických železných rudách.
Ve výbrusu napříč zploštělými ooidy pozorujeme, že dolní a horní část ooidu jsou tvořeny karbonátem, zatímco zóna kolem osní roviny uvnitř ooidu je tvořena kaolinitem (obr. 3A), který podle Petránka (1975) vzniká přeměnou z chloritů. Kaolinit tedy patrně vznikal v době, kdy zde působil orientovaný tlak. Kaolinit vznikl v důsledku rozpadu chloritu: $\mathrm{Fe}_{5} \mathrm{Al}_{2} \mathrm{Si}_{3} \mathrm{O}_{10}(\mathrm{OH})_{8}$ (Fe chlorit) $+5 \mathrm{CO}_{2}=\mathrm{Al}_{2} \mathrm{Si}_{2} \mathrm{O}_{5}(\mathrm{OH})_{4}$ (kaolinit) $+5 \mathrm{FeCO}_{3}$ (siderit)

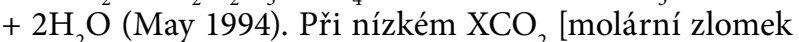
$\left.\mathrm{CO}_{2} /\left(\mathrm{H}_{2} \mathrm{O}+\mathrm{CO}_{2}\right)\right]$ je tato minerální asociace stabilní jen při velmi nízkých teplotách pod $50^{\circ} \mathrm{C}$ avšak při vysokém $\mathrm{XCO}_{2}$ je stabilní i při teplotách kolem $100{ }^{\circ} \mathrm{C}$ (May 1994). Teploty těchto přeměn však byly spíše nízké, protože nedošlo k rekrystalizaci kolofánu na apatit.

\section{Závěry}

Studované oolitické rudy z lokality Skalka u Mníšku se skládají hlavně ze sideritu a kaolinitu. Tato minerální asociace vznikla rozpadem chloritu a Fe oxo-hydroxidů $\mathrm{v}$ důsledku diagenetických pochodů. Vysoká převaha amorfního fosfátu nad krystalovaným apatitem dokládá, že teploty těchto přeměn byly nízké (pod $100^{\circ} \mathrm{C}$ ).

Zatímco Fe-ooidy jsou typickým produktem sedimentace na mělčinách, fosilní záznam břidlic šáreckého souvrství ukazuje na sedimentaci v podmínkách hlubšího sublitorálu až bathyálu (zhruba mezi 100 až $1000 \mathrm{~m}$ ). Ložisko oolitických rud Skalka proto nejspíše vzniklo redepozicí ooidů vlivem gravitačních proudů na podmoř ském svahu. Sedimentace hlavní rudní polohy probíhala $\mathrm{v}$ hypoxických podmínkách s anoxií pod rozhraním voda/sediment.

Faciální poměry a doložený fosilní záznam potvrzují existenci ploché elevace oddělující pražskou pánev od deprese, ve které sedimentovaly oolitické železné rudy ložiska Skalka. Tato deprese však byla součástí rozsáhlejší oblasti otevřeného moře, spíše než částečně izolovaným zálivem.

\section{Poděkování}

Předložená práce vznikla za finanční podpory interního projektů České geologické služby číslo 321180 („Základní geologické mapování"). Autoři děkují Janu Hoškovi za pomoc při prípravě článku a členům občanského sdružení Montánní společnost za pomoc sodběrem vzorků. Práškové rtg-difrakční analýzy byly provedeny za podpory výzkumné infrastruktury CEITEC Nano (ID LM2015041, MŠMT, 2016-2019), CEITEC Vysoké učení technické v Brně. Dík patří rovněž editorovi $M$. Slobodníkovi a recenzentưm J. Cempírkovi a F. Vackovi. 


\section{Literatura}

Bouček, B. (1947). O vývoji a paleogeografických poměrech českého staršího ordoviku. - Sborník Státního geologického ústavu, sv. XIV, Praha.

Bubík, M. (2001). Praha Vokovice - „Na Salátce“. - In: Bubík, M. (ed.): Fossil record of agglutinated rhizopods (foraminifers, testaceans) on the territory of Czech Republic. Field trip guide of the $6^{\text {th }}$ IWAF, Prague, September 1-7, 2001. - Czech Geological Survey, 20-22. Prague.

Dahanayake, K., Krumbein W. E. (1985). Ultrastructure of a microbial mat-generated phosphorite. - Mineralium Deposita, 20, 260-265. https://doi.org/10.1007/BF00204283

Drost, K., Gerdes, A., Jeffries, T., Linnemann, U., Storey, C. (2011). Provenance of Neoproterozoic and early Paleozoic siliciclastic rocks of the. Teplá-Barrandian unit (Bohemian Massif). Evidence from U-Pb detrital zircon ages. - Gondwana Research, 19, 213-231. https://doi.org/10.1016/j.gr.2010.05.003

Einsele, G. (1992). Sedimentary basins: evolution, facies, and sediment budget. - Berlin; New York: Springer-Verlag. 628 p.

Havlíček, V. (1981). Climatic changes and development of benthic communities through the Mediterranean Ordovician. - Sborník geologických věd, Geologie 44, 79-116. Ústřední ústav geologický.

Havlíček, V. (1986). Geologická mapa 1 : 50 000, list 12-41 Beroun. - Ústřední ústav geologický.

Hiatt, E. E., Pufahl, P. K., Edwards, C. T. (2015). Sedimentary phosphate and associated fossil bacteria in a Paleoproterozoic tidal flat in the 1.85 Ga Michigamme Formation, Michigan, USA. - Sedimentary Geology, 319:24-39. https://doi.org/10.1016/j. sedgeo.2015.01.006

Holcová, K. (1999). Foraminifers from the Barrandian: A revision of micropaleontological collection of the Department of Paleontology, Charles University Prague. - Časopis Národního Musea, 168, 1-4, 37-51.

Hošek, J. (2017). Petrografie oolitických železných rud z ložiska Skalka u Mníšku pod Brdy (Barrandien). - MS, bakalářská práce. Př́rodovědecká fakulta Masarykovy univerzity. Brno.

Chlupáč, I. (1992). Paleozoikum Barrandienu. - Vydavatelství Českého geologického ústavu, Praha. 292 s.

Chlupáč, I., Brzobohatý, T., Kovanda, J., Stráník, Z. (2002). Geologická minulost České republiky. - Academia, Praha. $436 \mathrm{~s}$

Kukal, Z. (1962). Petrografický výzkum vrstev šáreckých barrandienského ordoviku. -Sborník Ústředního ústavu geologického, oddíl geologický, 27 (1960), Praha.

Kukal, Z. (1963). Výsledky sedimentologického výzkumu barrandienského ordoviku. - Sborník geologických věd, řady Geologie, $1,103-138$.

Litochleb, J. (2012). Ložiska a výskyty nerostných surovin na území Brdských hřebenů a v jejich okolí (střední Čechy). - Bulletin mineralogicko-petrologického oddělení Národního muzea v Praze 20, 2, 129-175,

Mašek, J. (1999). Geologická mapa ČR 1: 50 000, list 12-43 Dobříš. - Český geologický ústav. Praha.

Petránek, J. (1965). Železné rudy českého ordoviku a tzv. rudní obzory. - Časopis pro mineralogii a geologii, 10, 4, Praha.

Petránek, J. (1975). Ložiska sedimentárních železných rud v Mníšku a Komárově. - Studie Československé Akademie Věd, 6, 7-99, Praha.

Pouchou, J. L., Pichoir, F. (1985). “PAP” ( $\varphi-\rho-Z)$ procedure for improved quantitative microanalysis. - In: Armstrong, J. T. (ed.). Microbeam Analysis. San Francisco Press, San Francisco, 104-106.

Skoček, V. (1963). Petrografické složení a geneze železných rud v oblasti Březiny. - Rozpravy Československé akademie věd 73, 4, 3-84, Praha.

Sturesson, U. (1995). Llanvirnian (Ord.) iron ooids in Baltoscandia: element mobility, REE distribution patterns, and origin of the REE. - Chemical Geology, 125, 45-60. https://doi.org/10.1016/S0037-0738(00)00091-9

Sturesson, U. (2003). Lower Palaeozoic iron oolites and volcanism from a Baltoscandian perspective. - Sedimentary Geology, 159, 241-256. https://doi.org/10.1016/S0037-0738(02)00330-5

Svoboda, J., Prantl, F. (1946). Geologický profil rudním ložiskem na Skalce u Mníšku. - Věstník Státního geologického ústavu Republiky Československé, 21, 3-6, 313-334.

von Raumer, J. F., Stampfli, G. M. (2008). The birht of the Rheic Ocean - Early Palaeozoic subsidence patterns and subsequent tectonic plate scenarios. - Tectonophysics, 461, 9-20. https://doi.org/10.1016/j.tecto.2008.04.012

Vtělenský, J. (1959). Mineralogie oolitických železných rud z některých ložisek Barrandienu. - Geotechnica, sv. 26, Nakladatelství ČSAV Praha.

Zelenka, J., Živor, R. (2019). Hornické památky České republiky. - Academia, Praha. 659 s. 